NEW DISEASE REPORT

\title{
First report of Pseudomonas cichorii on turmeric (Curcuma longa) in Brazil
}

\author{
A. C. Maringonia ${ }^{a \star}$, G. F. Theodoro ${ }^{b}$, L. C. Ming ${ }^{a}$, J. C. Cardoso and C. Kurozawa ${ }^{a}$ \\ a Department of Plant Production, Faculdade de Ciêncicas Agronômicas, São Paulo State University, PO Box 237, $18603-970$ Botucatu - \\ SP; and ${ }^{\mathrm{b} E P A G R I / C E P A F, ~ F i t o s s a n i t a r y ~ L a b o r a t o r y, ~ 89801-970 ~ C h a p e c o ́ ~-~ S C, ~ B r a z i l ~}$
}

In 2002 a serious leaf blight was observed on turmeric (Curcuma longa) plants grown for bulb multiplication in an experimental field at the Faculdade de Ciências Agronômicas, in Botucatu, State of São Paulo, Brazil. Affected leaves had irregular lesions that later enlarged and coalesced, resulting in part or whole leaf desiccation. Microscopic examination of tissue sections through lesion margins in sterile water revealed bacterial streaming. A mucoid, white bacterium was consistently isolated on King's medium B (King et al., 1954). A single pure culture of the bacterium was examined and was found to be a Gram-negative, rod-shaped, aerobic, oxidase- and catalasepositive, fluorescent bacterium, that utilized asparagine and did not produce a hypersensitive reaction on tobacco leaves (Lelliot \& Stead, 1987). The strain was analysed with the MicroLog2 System ${ }^{\circledR}$ (Biolog, Hayward, CA, USA) and identified as Pseudomonas cichorii with similarity index of $84.2 \%$ and a probability of $100 \%$. Leaves of 8 week-old plants of cv. Açafrão do Norte were inoculated using a toothpick dipped in a bacterial suspension $\left(10^{8}\right.$ cfu $\left.\mathrm{mL}^{-1}\right)$. Control plants were inoculated with water.
Disease symptoms were observed on leaves 5 days after inoculation and the inoculated bacterium was re-isolated from lesions. Control plants remained disease-free. Turmeric is not reported as host of P. cichorii (Bradbury, 1986). In Brazil this bacterium has previously been reported to cause disease on several cultivated plants (Marques et al., 1994) but this is the first report on turmeric.

\section{References}

Bradbury JF, 1986. Guide to Plant Pathogenic Bacteria. Kew, UK: CAB International Institute.

King EO, Ward MK, Raney DE, 1954. Two simple media for the demonstration of pyocyanin and fluorescein. Journal of Laboratory and Clinical Medicine 44, 301-7.

Lelliott RA, Stead. DE, 1987. Methods for the Diagnosis of Bacterial Diseases of Plants. Oxford, UK: Blackwell Scientific Publications.

Marques AB, Robbs CF, Boitox LS, Parente PMG, 1994. Índice de Fitobacterioses Assinaladas no Brasil. Brasília: Empresa Brasileira de Pesquisa Agropecuária.

*E-mail: maringoni@fca.unesp.br

Accepted 7 April 2003 at http://www.bspp.org.uk/ndr

where figures relating to this paper can be viewed. 